\title{
Resistin, A Potential Actor in Coronary Artery Disease
}

\section{Resistin, Koroner Arter Hastalığında Potansiyel Bir Aktör}

\section{Elif KILIC', Nezaket EREN², Cevat KIRMA³, Şebnem CIGERLI², Fatma TURGAY², Saban YAYLA², Abdurrahim KOCYIGIT \\ ${ }^{1}$ Department of Biochemistry, Bezmialem Vakif University Faculty of Medicine, Istanbul, Turkey \\ ${ }^{2}$ Department of Biochemistry, Sisli Hamidiye Etfal Training and Research Hospital, Istanbul, Turkey \\ ${ }^{3}$ Department of Cardiology, Kartal Kosuyolu Yuksek Ihtisas Training and Research Hospital, Istanbul, Turkey}

\section{ABSTRACT}

Objective: Biochemical observations of the decrease in mortality rate and prediction of the degree of coronary artery stenosis before symptomatic improvement are gaining importance. In our study, we aimed to evaluate the etiological value of the recently discovered resistin biomolecule in coronary atherosclerosis pathogenesis.

Methods: In this study, we evaluated and compared serum resistin levels in patients with angiographically proven coronary artery disease (stenosis ratio $>25 \%)(n=43)$ and in the control group with angiographically proven normal coronary artery diameter (stenosis ratio <25\%) $(\mathrm{n}=25)$. Furthermore, serum glucose, insulin, total cholesterol, high-density lipoprotein (HDL), low-density lipoprotein (LDL), homocysteine, and high-sensitivity C-reactive protein (hsCRP) levels and homeostatic model assessment- insulin resistance (HOMA-IR) were evaluated to compare resistin with other etiological factors.

Results: Resistin levels were higher in the patient group (2.32 \pm 1.1$)$ than the control group $(2.25 \pm 0.7)$, but no significant difference was found between the groups $(\mathrm{p}=0.773)$. Resistin levels were significantly lower in antihyperlipidemic agent users in both patient and control groups $(\mathrm{p}<0.05)$. Other group characteristics did not show significant differences in resistin levels $(p>0.05)$. While considering both patient and control group correlations, we determined a positive correlation between resistin and fasting insulin ( $\mathrm{p}=0.012, \mathrm{r}=0.304)$, HOMA-IR ( $\mathrm{p}=0.046, \mathrm{r}=0.243)$, homocysteine ( $\mathrm{p}=0.05 ; \mathrm{r} 0.239)$, and hsCRP ( $\mathrm{p}=0.029, \mathrm{r}=0.265)$.

Conclusion: Resistin values differ between patients and control subjects but were not statistically significant. The modifying effect of anti-hyperlipidemic agents over serum resistin levels may have a preventive role in the process of atherosclerosis. We think that effective results will be obtained in raising the selected threshold level of atherosclerosis diagnosis and increasing the number of patients.

Key Words: Resistin, coronary artery disease, hsCRP, inflammation

\section{ÖZET}

Amaç: Koroner arter hastalığında, yüksek mortalite oranlarının düşürülmesi ve koroner darlık derecesinin semptomatik dereceye ulaşmadan önce öngörülebilmesinde biyokimyasal parametrelerin kullanılması son yıllarda önem kazanmaktadır. Bu çalışmada, adipoz doku kaynaklı bir sitokin olan resistin biyomolekülünün koroner ateroskleroz etyolojisindeki rolünü ve tanısal değerini incelemeyi amaçladık. Yöntemler: Bu çalışmada, anjiyografik olarak koroner arter hastalığı tanısı alan grupla (darlık oranı $>\% 25)(\mathrm{n}=43)$, normal koroner arter lümen çapı (darlık oranı <\%25) bulunan kontrol grubunun $(\mathrm{n}=25)$ anjiyografi işlemi öncesinde alınan serumlarında resistin düzeyleri karşılaştırıldı. Ayrıca diğer etyolojik faktörler ile karşılaştırılması amacıyla serum glukoz, insülin, total kolesterol, yüksek dansiteli lipoprotein (HDL), düşük dansiteli lipoprotein (LDL), homosistein, yüksek sensitiviteli C-reaktif protein (hsCRP) düzeyleri ve homeostatik model insülin direnci (HOMA-IR) değerlendirildi.

Bulgular: Hasta grubunun resistin ortalaması $(2,32 \pm 1,1)$, kontrol grubuna $(2,25 \pm 0,7)$ göre yüksek olup istatistiksel olarak anlamlı farklılık saptanmadı ( $\mathrm{p}=0,773)$. Hasta ve kontrol gruplarında anti-hiperlipidemik ajan kullanmayanlarda kullananlara göre resistin seviyeleri anlamlı yüksek bulundu $(\mathrm{p}<0.05)$. Diğer grup özelliklerine göre resistin seviyeleri arasında anlamlı fark saptan$\operatorname{mad}_{1}(\mathrm{p}>0.05)$. Tüm grupların korelasyonuna baktığımızda ise resistin ile açlık insülini ( $\mathrm{p}=0,012, \mathrm{r}=0,304), \operatorname{HOMA-IR}(\mathrm{p}=0,046$, $\mathrm{r}=0,243)$, homosistein ( $\mathrm{p}=0,05, \mathrm{r}=0,239)$ ve hsCRP ( $\mathrm{p}=0,029$, $\mathrm{r}=0,265$ ) düzeyleri arasında pozitif korelasyon saptand.

Sonuç: Resistin seviyeleri, hasta ve kontrol grubu arasında farklılık göstermekle birlikte istatistiksel olarak anlamlı bulunmadı. Ateroskleroz sürecinde önleyici rolü olan anti-hiperlipidemik ajan kullanımının serum resistin düzeyini değiştirmesi, etyolojideki belirteçler ile arasında korelasyon bulunması biyomolekülün etkinliği açısından ipuçları vermektedir. Seçilen hastalık eşik tanı değerinin yükseltilmesi ve hasta sayısının artırılması ile etkin sonuçlar alınabileceğini düşünmekteyiz.

Anahtar Sözcükler: Resistin, koroner arter hastalığı, Hs CRP, inflamasyon 


\section{Giriş}

Kardiyovasküler hastalıklar endüstrileşmiş toplumlarda ölümlerin en sık nedenidir. Amerika Birleşik Devletleri'nde kardiyovasküler hastalıklara bağlı ölüm oranı 2010 yılında \%32,4 olup, ölüm oranlarında birinci sırada yer almaktadır. Kardiyovasküler hastalıkların yarıdan fazlası ise aterosklerotik koroner arter hastalığına (KAH) bağlıdır $(1,2)$. Ülkemizde ise Türk Kardiyoloji Derneği'nin öncülüğünde 1990-2008 yılları arasında yapılan TEKHARF (Türk Erişkinlerinde Kalp Hastalığı ve Risk Faktörleri) çalışmasının 18 yıllık izlem verilerine göre, 35 yaş üzerindeki 29,5 milyon nüfusta 3,1 milyon kişinin, yani her bin yetişkinden $105^{\prime}$ inin koroner arter hastası olduğu ve KAH'ın nüfus artışı ve nüfusun yaşlanmasından bağımsız, hayat tarzımıza bağlı değişiklikler sonucu yılda ortalama $\% 3$ arttığı tespit edilmiştir. Bununla birlikte ölüm nedenleri arasinda KAH \%40 oranıyla 1. sırada yer almaktadır (3).

KAH'ın temelini oluşturan ateroskleroz; aortadan epikardiyal koroner arterlere kadar değişen büyüklükte sistemik arterlerin etkilendiği kronik bir hastalıktır (4). Koroner kalp hastalığı klinik olarak ortaya çıktıktan sonra uygulanan tıbbi, cerrahi ve girişimsel tedavi yöntemleri kompleks bir sürece sahip olup, oldukça yüksek bir maliyeti beraberinde getirmektedir. Buna bağlı olarak KAH'ın başlangıç lezyonu olan ateroskleroz basamağının oluşumunun engellenmesi, en önemli primer korunma adımını oluşturur.

Araştırmalar aterosklerozun basitce, damar duvarındaki bir lipid birikimini simgelemekten öte, inflamatuar bir hastalık olduğunu düşündürmektedir. Yapılan son hayvan modelli çalışmalarda inflamasyonun, aterosklerozun oluşum ve şiddetinden daha çok plak rüptürü ve sonrasında gelişen tromboziste etkin olduğu gösterilmiştir. Bugün için, inflamasyonla ilişkili 20 'den fazla hücre adezyon molekülü ve yaklaşık 50 proinflamatuar sitokin tanımlanmıştır. Bunların önemli bir kısmı da insan aterosklerotik plaklarında saptanmıştır (5-8). $\mathrm{Bu}$ sitokinler arasında olduğu düşünülen resistin, $12,5 \mathrm{kDa}$ ağırlığında sisteinden zengin bir adipokindir. Fizz3 proteini olarak da adlandırılır. Yağlanmayla birlikte artan resistin, adiponektinin aksine özellikle kemirgenlerde insülin rezistansına ve tip 2 diyabete yol açabilmektedir.

Resistinin insanlardaki asıl kaynağı makrofajlardır. İn vitro olarak makrofaj stimülasyonu ve eksojen endotoksin uygulanması, resistin üretiminde artışa yol açar. Bunun sonucunda da resistinin sepsisle ve diğer inflamatuar hastalıklarla ilişkili olduğu gösterilmiştir. Resistin damar duvarında VCAM-1, ICAM-1, MCP-1 ve endotelin-1 gibi adezyon moleküllerinin üretimini arttırdığından dolayı vasküler endotel hücrelerinde direkt pro-inflamatuvar etkiye sahiptir $(9,10)$.

Resistinin insülin rezistansı, obezite ve tip 2 diyabet gibi hastalıklardaki rolü tam olarak açıklanamasa da bu hastalıklardaki artışı birçok çalışmayla gösterilmiştir. Resistinin inflamatuvar yolaklar ve düz kas hücre proliferasyonunu stimüle eden etkisi ile endotelyal hücrelerin aktivasyonu yeni keşfedilmiş ve bu etkilerinin vasküler hastalıklarda etyolojik bir faktör olabileceği düşünülmüştür $(11,12)$.

Çalışmamızda, KAH bulunan bireylerde serum resistin düzeylerini ölçerek, resistin seviyesindeki değişikliklerin, kardiyovasküler hastalıklar için bir belirteç sayılıp sayılamayacağını değerlendirmeyi amaçladık.

\section{Yöntemler}

Çalışmamıza Kartal Koşuyolu Yüksek İhtisas Eğitim ve Araştırma Hastanesi' ne başvuran, efor testi veya miyokard perfüzyon sintigrafisinde iskemik değişiklikler tespit edilerek konvansiyonel anjiyografi uygulanan 22'si kadın (\%32,3), 46's1 erkek $(\% 67,6)$ olmak üzere 68 olgu dahil edildi. Çalışma için gerekli olan etik kurul onayı Şişli Hamidiye Etfal Eğitim ve Araştırma Hastanesi" Etik Kurulu'ndan alındı. Çalışmaya dahil edilen hastaların onam formu yazılı olarak tüm hastalardan alındı.

Anjiyografik olarak KAH tespit edilen (\%25'den fazla oranda darlık bulunan koroner arter segmenti) 43 olgu hasta grubumuzu (KAH (+) ), normal koroner arter lümen çapı $(<\% 25)$ izlenen 25 olgu ise kontrol grubumuzu (KAH (-)) oluşturdu. Diyabet tanısı için kullandığımız eşik değer Amerikan Diyabet Derneği' nin kriterlerine göre belirlendi (13). Anti-hipertansif bir ajan kullanılsın veya kullanılmasın, yaşamının herhangi bir safhasında hipertansiyonu olduğunu bildiriyorsa bu hipertansiyon öyküsü açısından pozitif kabul edildi. Dislipidemi tanısı için kullandığımız eşik değerler Türk Kardiyoloji Derneği Koroner Kalp Hastalığı Korunma ve Tedavi Kılavuzu 2002'ye göre belirlendi. Bu analiz sonucu total kolesterol düzeyi $200 \mathrm{mg} / \mathrm{dL}$ ve üzerinde, LDL düzeyi $130 \mathrm{mg} / \mathrm{dL}$ ve üzerinde olan vakalar dislipidemik olarak değerlendirildi.

Boy ve kilo ölçümleri yapılarak Vücut kitle indeksi $\left(\mathrm{VKI}=\left(\operatorname{ağ} ı r l ı k(\mathrm{~kg}) / \mathrm{boy}^{2}\left(\mathrm{~m}^{2}\right)\right)\right.$ hesaplandı. VKI $30 \mathrm{~kg} / \mathrm{m}^{2}$ ve üzeri olanlar obez, $25-30 \mathrm{~kg} / \mathrm{m}^{2}$ olanlar fazla kilolu, $19-25 \mathrm{~kg} /$ $\mathrm{m}^{2}$ olanlar normal kilolu, $18,5 \mathrm{~kg} / \mathrm{m}^{2}$ den düşük olanlar zayıf olarak değerlendirildi. İnsülin direnci, HOMA-IR indeksi (açlık insülini $(\mathrm{mU} / \mathrm{L}) \mathrm{x}$ açlık glukozu $(\mathrm{mmol} / \mathrm{L}) / 22,5)$ kullanılarak değerlendirildi. HOMA-IR skoru $\geq 2,5$ olan hastalar insülin direnci pozitif (HOMA-IR $(+)$ ) olarak kabul edildi.

Hastaların ve kontrol grubunun ortalama 12 saatlik açlık sonrası sabah 8:00 - 9:00 saatleri arasında jelli tüpe alınan venöz kan örnekleri 10 dakika süreyle 3600 devir/dakika santrifüj edilerek serumlar ayrıldı. Elde edilen serumlardan glukoz (hekzokinaz yöntemi, Olympus AU 2700), total kolesterol (enzimatik kolorimetrik yöntem, Olympus AU 2700), yüksek dansiteli lipoprotein (HDL) (enzimatik kolorimetrik yöntem, Olympus AU 2700), LDL (Friedewal formülü kullanılarak), hsCRP (immun türbidimetrik yöntem, Olympus AU 2700), homosistein (kemülimünesan immunoassay yöntem, Immulite 2000) ve insülin (kemiluminesan sandviç immun testi, Advia Centaur XP) düzeyleri ticari kitler kullanılarak ölçüldü.

\section{Serum Resistin Düzeylerinin Ölçümü}

Resistin ölçümü için tüm olguların serumları ependorf tüplerine aktarıldıktan sonra Elisa kiti kullanım kılavuzundaki 
Tablo 1. Hasta ve kontrol gruplarına ait demografik özellikler

\begin{tabular}{|c|c|c|c|c|c|c|c|c|c|c|c|c|}
\hline & \multicolumn{4}{|c|}{ Cinsiyet } & \multirow{2}{*}{$\begin{array}{c}\text { Yaş } \\
\text { ortalaması }\end{array}$} & \multirow{2}{*}{$\begin{array}{c}\text { Boy } \\
\text { ortalaması } \\
(m)\end{array}$} & \multirow{2}{*}{$\begin{array}{c}\text { Kilo } \\
\text { ortalaması } \\
\text { (kg) }\end{array}$} & \multirow[b]{2}{*}{ VKi } & \multicolumn{4}{|c|}{ Sigara } \\
\hline & erkek & $\%$ & kadın & $\%$ & & & & & evet & $\%$ & hayır & $\%$ \\
\hline Kontrol $(n=25)$ & 10 & 40 & 15 & 60 & $54,48 \pm 11,45$ & $1,65 \pm 0,1$ & $81,88 \pm 17,26$ & $30,15 \pm 6,26$ & 11 & 44 & 14 & 56 \\
\hline Hasta $(n=43)$ & 36 & 83,7 & 7 & 16,3 & $57,74 \pm 11,00$ & $1,69 \pm 0,1$ & $79,23 \pm 11,78$ & $27,82 \pm 4,39$ & 12 & 27,9 & 31 & 72,1 \\
\hline Toplam ( $\mathrm{n}=68)$ & 46 & 67,6 & 22 & 32,4 & $56,54 \pm 11,19$ & $1,67 \pm 0,1$ & $80,20 \pm 13,98$ & $28,68 \pm 5,24$ & 23 & 33,8 & 45 & 66,2 \\
\hline
\end{tabular}

saklama koşul ve süresi göz önünde bulundurularak çalışmanın yapılacağı güne kadar $-80^{\circ} \mathrm{C}$ 'de saklandı. Çalışmanın yapılacağı gün oda ısısına getirilen örneklerde, ETI-Max 3000 (DiaSorin, İtaly) cihazında Human Resistin ELISA Kiti (AssayMax) kullanılarak serum resistin düzeylerinin kantitatif tayini yapıld.

\section{İstatistiksel analiz}

Verilerin istatistiksel değerlendirilmesinde statistical package for the social sciences (SPSS) for Windows 15.0 programı kullanıldı. Parametrik verilerin analizinde Student's T testi ve ANOVA analizi, parametrik olmayan verilerin değerlendirilmesinde Mann Whitney U ve Ki-kare testleri kullanıldı. Korelasyon analizlerinde Pearson ve Spearman korelasyon analizleri kullanıldı. $\mathrm{p} \leq 0,05$ düzeyi anlamlı olarak kabul edildi.

\section{Bulgular}

Çalışma grubunun tüm demografik verileri ve çalışılan parametreler Tablo 1 ve Tablo 2'de verilmiştir. Hasta grubunun $(n=43)$ glukoz ve resistin ortalamaları kontrol grubuna $(n=25)$ göre daha yüksek olup istatistiksel olarak anlamlı farklılık saptanmadi (sırasıla $p=0,073$ ve $p=0,773$ ). Hasta ve kontrol grupları arasında, total kolesterol, HDL, LDL, insülin, homosistein, hsCRP düzeyleri ve HOMA-IR açısından anlamlı farklılık saptanmadı (Tablo 2).

Tüm olgularda resistin değerlerini diyabet, hipertansiyon, dislipidemi, sigara kullanımı ve AHLA (Antihiperlipidemik ajan) kullanımı olan ve olmayan gruplar açısından incelediğimizde, diyabetik olan olguların resistin ortalama değerleri diyabetik olmayan gruba göre yüksek fakat anlamlı değildi $(\mathrm{p}=0,587)$. Dislipidemik olguların ortalama resistin değerleri dislipidemisi olmayanlara göre daha yüksek fakat istatistiksel olarak anlamlı değildi ( $\mathrm{p}=0,213)$. AHLA kullanmayanlarda ise kullananlara göre resistin ortalamaları anlamlı olarak yüksekti $(p=0,029)$ (Tablo 3). Hasta ve kontrol gruplarını ayrı ayrı DM, HT ve dislipidemisi olan ve olmayan gruplar olarak ayırdığımızda, hs CRP, homosistein ve HOMA-IR düzeyleri açısndan gruplar arasında anlamlı farklılık saptanmadı. Sadece hasta grubundaki hipertansif bireylerde LDL düzeyleri anlamlı olarak yüksek bulundu $(\mathrm{p}=0,044)$.

Hasta ve kontrol grubunu ayrı ayrı kendi içinde değerlendirdiğimizde; hasta grubunda total kolesterol ve HOMA-IR

\begin{tabular}{|c|c|c|c|}
\hline & & $\begin{array}{c}\text { Resistin(ng/mL) } \\
\text { Mean士SD }\end{array}$ & $\stackrel{\text { p }}{\text { değeri }}$ \\
\hline Diabetesmellitus & $\begin{array}{l}\text { var } \\
\text { yok }\end{array}$ & $\begin{array}{l}2,39 \pm 0,78 \\
2,25 \pm 1,07\end{array}$ & 0,587 \\
\hline Hipertansiyon & $\begin{array}{l}\text { var } \\
\text { yok }\end{array}$ & $\begin{array}{l}2,18 \pm 0,72 \\
2,44 \pm 1,22\end{array}$ & 0,286 \\
\hline Sigara kullanımı & $\begin{array}{l}\text { var } \\
\text { yok }\end{array}$ & $\begin{array}{l}2,47 \pm 1,21 \\
2,21 \pm 0,83\end{array}$ & 0,292 \\
\hline Dislipidemi & $\begin{array}{l}\text { var } \\
\text { yok }\end{array}$ & $\begin{array}{l}2,36 \pm 1,00 \\
1,97 \pm 0,80\end{array}$ & 0,213 \\
\hline AHLA kullanımı & $\begin{array}{l}\text { var } \\
\text { yok }\end{array}$ & $\begin{array}{l}1,76 \pm 0,52 \\
2,42 \pm 1,02\end{array}$ & 0,029 * \\
\hline Cinsiyet & $\begin{array}{l}K \\
E\end{array}$ & $\begin{array}{l}2,28 \pm 1,09 \\
2,34 \pm 0,69\end{array}$ & 0,808 \\
\hline
\end{tabular}

$\mathrm{r}=-0,333)$. HOMA-IR ile insulin ve glukoz düzeyleri arasında anlamlı ve pozitif korelasyon saptand $(r=0,881, r=0,306)$. Kontrol grubunda ise insülin ile LDL düzeyleri arasında anlamlı fakat negatif korelasyon mevcuttu ( $\mathrm{p}=0,033, \mathrm{r}=-0,428)$. Ínsulin ve HOMA-IR düzeyleri arasında pozitif ve anlamlı korelasyon saptand $(\mathrm{p}=0,001, \mathrm{r}=0,973)$.

Hasta grubu kendi içerisinde değerlendirildiğinde insulin ve kilo ile resistin düzeyleri arasında anlamlı korelasyon saptandı. (sırasiyla $\mathrm{p}=0,012, \mathrm{r}=0,380, \mathrm{p}=0,046, \mathrm{r}=0,306$ ). Resistin ile glikoz, HOMA-IR, total kolesterol, HDL, LDL, homosistein, hsCRP arasında anlamlı korelasyon saptanmadı (Tablo 4).

\section{Tartışma}

Aterosklerozun, basitçe, damar duvarındaki lipid birikimini simgelemekten öte daha dinamik ve inflamatuvar özellikte bir hastalık olduğu araştırmalarla gösterilmiştir $(6,14,15)$. Resistinin inflamatuvar yolaklar ve düz kas hücre proliferasyonunu stimüle eden etkisi ile endotelyal hücrelerin aktivasyonu bilgisi ise yeni keşfedilmiş ve bu etkilerinin vasküler hastalıklarda etyolojik bir faktör olabileceği düşünülmüştür $(11,12)$.

Resistin düzeyleri ve miyokard enfarktüsü riski ilişkisi üzerine yapılmış ilk prospektif kohort çalışması European Prospective Investigation into Cancer and Nutrition (EPIC)-postdam 
Tablo 3. Tüm olguların (hasta ve kontrol gruplarının) Resistin Değerlerinin Istatistiki Olarak Karşılaştırılması

\begin{tabular}{|c|c|c|c|c|c|c|c|c|}
\hline $\begin{array}{l}\text { GLUKOZ } \\
\text { (mg/dL) }\end{array}$ & $\begin{array}{l}\text { Total Kolesterol } \\
\text { (mg/dL) }\end{array}$ & $\begin{array}{c}\mathrm{HDL} \\
(\mathrm{mg} / \mathrm{dL})\end{array}$ & $\begin{array}{c}\text { LDL } \\
\text { (mg/dL) }\end{array}$ & $\begin{array}{l}\text { Insülin } \\
\text { (mU/L) }\end{array}$ & $\begin{array}{c}\text { Homosistein } \\
\text { ( } \mu \mathrm{mol} / \mathrm{L})\end{array}$ & $\begin{array}{c}\text { hHsCRP } \\
\text { (mg/L) }\end{array}$ & & $\begin{array}{l}\text { Resistin } \\
\text { (ng/mL) }\end{array}$ \\
\hline rtalama $\pm S D$ & Ortalama \pm SD & Ortalama \pm SD & Ortalama $\pm S D$ & Ortalama $\pm S D$ & Ortalama \pm SD & Ortalama \pm SD & \pm SD & Ortalama \pm SD \\
\hline $105,72 \pm 20,59$ & $184,04 \pm 42,4$ & $43,04 \pm 13$ & 5,90 & 12,60 & $11, \varepsilon$ & 5,2 & $=3,2$ & $\pm 0,7$ \\
\hline $131,81 \pm 69,79$ & $188,55 \pm 45,0$ & $38,28 \pm 11,9$ & $120,35 \pm 35,2$ & $16,86 \pm 18,8$ & $12,91 \pm 5,6$ & $5,47 \pm 6,0$ & $5,46 \pm 6,7$ & $2,32 \pm 1,1$ \\
\hline 0,073 & 0,685 & 0,131 & 0,626 & 0,317 & 0,440 & 0,858 & 0,147 & 0,773 \\
\hline
\end{tabular}

VKi: vücut kitle indeksi; HDL:yüksek dansiteli lipoprotein; LDL: düşük dansiteli lipoprotein; HsCRP:yüksek sensitiviteli C reaktif protein; HOMA-IR: homeostatic model assessmentinsülin resistance

çalışma grubu tarafından yapılmıştır. 1994-1998 yılları arasında, 35-65 yaş aralığında miyokard infarktüsü (MI) ve iskemik inme (IS) hikayesi olmayan 26,490 kişi üzerinde 6 yıl süren izlem sonucunda bu kişilerden MI geçiren 139 kişi ve IS geçiren 97 kişi olmak üzere toplam 1053 kişinin katıllmıyla yaptıkları kohort çalışmasında; yüksek serum resistin seviyelerinin artmış MI riskiyle anlamlı olarak ilişkili $(\mathrm{p}=0,01)$ olduğunu ancak IS ile herhangi bir ilişkisi olmadığını göstermişlerdir (16). Bir başka geniş kapsamlı kohort çalışmasında ise toplam 547 hasta çalışmaya dahil edilmiş olup anjiyografik olarak koroner arterlerde $\geq \% 50$ den fazla darlık olan hastalar $(\mathrm{n}=217)$ ve darlık olmayan hastalar $(\mathrm{n}=330)$ gruplara ayrılmış ve bu iki grup arasında resistin değerleri açısından anlamlı bir fark tespit edilememiştir $(p=0,265)$ (17). Anjiyografik olarak KAH tanısı almış 185 kadın hasta ile anjiyografik olarak KAH tanısı almamış olan 227 kadın kontrol ile yapılan çalışmada ise resistin seviyeleri hasta bireylerde kontrol grubundakilere göre anlamlı olarak yüksek bulunmuştur (kontrol grubu ortalama değeri: 3,47; hasta grubun ortalama değeri: $4,10 \mathrm{ng} /$ $\mathrm{mL}, \mathrm{p}<0,001)$ (18). MI sonrasinda incelenen 100 hasta ve KAH hikayesi olmayan 100 kontrol vakası üzerine yapılan çalışmada ise hastalarda resistin seviyeleri anlamlı derecede yüksek bulunmuştur (hasta ortalama resistin değeri: $3,4 \mathrm{ng} / \mathrm{mL}$, kontrol ortalama resistin değeri: $2,8 \mathrm{ng} / \mathrm{mL}, \mathrm{p}=0,003)(19)$. Bizim çalışmamızda ise hasta grubunun ortalama resistin seviyesi kontrol grubuna göre yüksek bulundu fakat bu yükseklik anlamlı değildi $(2,32 \mathrm{ng} / \mathrm{mL} / 2,25 \mathrm{ng} / \mathrm{mL}, \mathrm{p}=0,773)$.

Resistin, insülinin uyardığı glukozun hücre içine alınımını bozar, hepatik glukoz üretimini arttırır ve glukoz toleransında bozulma nedeniyle insülin direnci gelişmesine yol açar. Serum resistin düzeyleri obezitede yükselmiş olup beden kitle indeksinden ziyade bel çevresi artışı ve visseral obeziteyle pozitif ilişki içindedir $(20,21)$. Çalışmamızda kontrol grubunun BKI değerlerinin hasta grubuna göre yüksek olduğu ancak istatistiksel olarak anlamlı olmadığı görülmüştür $(\mathrm{p}=0,066)$ (Tablo 1). Ayrıca, diğer çalışmalar ve literatür bilgisine paralel olarak tüm grupların korelasyonuna baktığımızda, resistin ile açık insülin ( $\mathrm{p}=0,012, \mathrm{r}=0,304)$ ve insulin direncinin göstergesi olan HOMA-IR ( $\mathrm{p}=0,046, \mathrm{r}=0,243)$ düzeyleri arasında pozitif bir korelasyon saptandı. Grupları kendi içinde ayrı ayrı değerlendirdiğimizde hasta olan grupta resistin değerleri ile vücut ağırlığı ve insülin düzeyleri arasında pozitif bir korelasyon mevcuttu ( $p=0,046 ; r=0,306 ; p=0,012 ; r=0,380)$. Hasta ve kontrol grubunda resistin ortalamalarını kıyasladığımızda,
Tablo 4. Kontrol ve Hasta grupları kendi içinde değerlendirildiğinde, diğer parametrelerin resistin ile ilişkisini gösteren korelasyon tablosu

\begin{tabular}{|c|c|c|c|c|}
\hline & \multicolumn{2}{|c|}{$\begin{array}{c}\text { Kontrol Grubu } \\
(\mathrm{n}=25) \\
\text { Resistin }\end{array}$} & \multicolumn{2}{|c|}{$\begin{array}{l}\text { Hasta Grubu } \\
\qquad(n=43)\end{array}$} \\
\hline & $\mathbf{p}$ & $r$ & $\mathbf{p}$ & $r$ \\
\hline Yaş & 0,537 & $-0,129$ & 0,336 & $-0,15$ \\
\hline Kilo & 0,728 & $-0,073$ & 0,046 & 0,306 \\
\hline VKi & 0,967 & $-0,009$ & 0,16 & $-0,218$ \\
\hline Glikoz & 0,658 & $-0,093$ & 0,256 & 0,177 \\
\hline Total kolesterol & 0,84 & $-0,042$ & 0,625 & 0,077 \\
\hline HDL & 0,408 & $-0,173$ & 0,105 & $-0,251$ \\
\hline LDL & 0,876 & $-0,033$ & 0,238 & 0,184 \\
\hline İnsülin & 0,878 & $-0,032$ & 0,012 & 0,38 \\
\hline Homosistein & 0,454 & 0,157 & 0,08 & 0,274 \\
\hline HsCRP & 0,262 & 0,233 & 0,07 & 0,279 \\
\hline HOMA-IR & 0,857 & $-0,038$ & 0,059 & 0,29 \\
\hline
\end{tabular}

AHLA kullanmayanlarda kullananlara göre resistin seviyeleri anlamlı yüksek bulundu $(\mathrm{p}<0,05)$.

Kontrol grubumuzu iskemik şikayetleri olan ve anjiyografik olarak koroner arterlerinde darlık tespit edilmeyen $(<\% 25)$ bireylerden oluşturmuştuk. Her ne kadar anlamlı darlık tespit etmesekte, ateroskleroz gelişiminin kronik bir süreç olması nedeni ile, kontrol grubumuzda erken evredeki aterom plakları mevcut olabilir. Resistinin adipoz doku kaynaklı oluşu dislipidemiden etkilenmesini gerektirir. Kontrol ve hasta grubunun dislipidemi profilinin çok benzer oluşu, ayrıca BKI değerlerinin kontrol grubunda benzer veya yüksek oluşu da aradaki farkın anlamsız olmasına yol açmış olabilir.

C-reaktif protein (CRP) yıllarca doku hasarı ve enflamasyonun teşhisinde yararlanılan bir parametre olmasına rağmen, son yıllarda kardiyovasküler hastalıkların teşhisinde de kullanılmaya başlanmıştır. Ayrıca aterosklerotik plaktaki CRP mRNA'sı, karaciğerdekinin 7 katı, normal damarlardakinin ise 10 katı miktarda bulunmuştur (22). Resistin düzeyinin 
de inflamatuar olaylarda artış gösterdiği çeşitli çalışmalarda gösterilmiştir $(23,24)$. Son yıllarda yapılan çalışmalardan resistinin bilinenin ötesinde çok etkin ve hayati mekanizmalarla önemli bir yere sahip olduğu da gösterilmiştir. Prugger ve ark. yaptığı geniş kapsamlı kohort çalışmasında resistinin iskemik inme riskinin tahmininde geleneksel risk faktörlerine belirgin olarak katkı sağladığ

HsCRP gibi inflamasyon belirteci olan parametreler, kontrol grubumuzda hasta grubunun değerlerine çok yakın değerlerdeydi. Kontrol grubunun inflamatuvar parametrelerindeki bu yükseklik, resistin değerlerinin yükselmesine ve anlamsız bir farka neden olmuş olabilir. Hiperhomosisteinemi ateroskleroz için bağımsız bir risk faktörü olarak tanımlanmaktadır. Kandaki homosistein düzeyinin, metabolizmasındaki genetik bir azalmaya bağlı olarak yükselmesi, damar endotelinde hasara yol açabilir. Bu da damarların aterosklerotik süreçlere yatkınlığı arttırır (26). Bizim çalışmamızda resistin düzeyleri ile homosistein ( $\mathrm{p}=0,050$, $r=0,239)$ ve hsCRP ( $p=0,029, r=0,265)$ düzeyleri arasında pozitif korelasyon saptandı. Ayrıca iskemi şikayetleri olan ve anjiyografi uygulanan bu grupta inflamatuvar parametreler (hsCRP, resistin), homosistein ve lipid düzeyleri hasta olan grubumuz ile benzer olması beklenilen bir durumdu.

\section{Sonuç}

Resistin artışının erken dönemlerdeki etkileri, düşük darlık safhalarındaki kontrol grubunda ölçülmüş olabilir. Ayrıca, sağlıklı bireylerde anjiyografi uygulanmasının kontrendike oluşu mutlak karşılaştırma yapabilmemiz açısından kısıtlayıcı bir etkendir. Kontrol ve hasta grubunun daha spesifik ve geniş kapsamlı olarak seçilmesi, özellikle dislipidemi ve inflamasyon belirteçleri yönünden inceleme parametrelerinin daha uzun soluklu olarak takip edilmesi, yeni yapılacak çalışmalarda resistinin koroner arter hastalığındaki rolünü daha net gösterebileceğine inanmaktayı.

Ethics Committee Approval: Ethics committee approval was received for this study from the ethics committee of Sisli Etfal Training and Research Hospital (29.06.2010/11).

Informed Consent: Written informed consent was obtained from all patients who participated in this study .

Peer-review: Externally peer-reviewed.

Author Contributions: Concept - E.K., N.E.; Design - E.K., S.C.; Supervision - E.K., F.T.; Funding - N.E., S.C.; Materials - E.K., N.E.; Data Collection and/or Processing -E.K., S.C.; Analysis and/or Interpretation - E.K., N.E.; Literature Review - E.K., S.Y.; Writing - E.K., A.K.; Critical Review - N.E., S.C.; Other - A.K.

Conflict of Interest: No conflict of interest was declared by the authors.

Financial Disclosure: The authors declared that this study has received no financial support.

Etik Komite Onayı: Bu çalışma için etik komite onayı Sisli Hamidiye Etfal Eğitim ve Araştırma Hastanesi'nden alınmıştır (29.06.2010/11).
Hasta Onamı: Yazılı hasta onamı bu çalışmaya katılan hastalardan alınmıştır.

Hakem değerlendirmesi: Dış bağımsız.

Yazar Katkıları: Fikir - E.K., N.E.; Tasarım - E.K., S.C.; Denetleme - E.K., F.T.; Kaynaklar - N.E., S.C.; Malzemeler - E.K., N.E.; Veri Toplanması ve/ veya İşlemesi - E.K., S.C.; Analiz ve/veya Yorum -E.K., N.E.; Literatür Taraması - E.K., S.Y.; Yazıyı Yazan -E.K., A.K.; Eleştirel İnceleme - N.E., S.C.; Diğer - A.K.

Çıkar Çatışması: Yazarlar çıkar çatışması bildirmemişlerdir.

Finansal Destek: Yazarlar bu çalışma için finansal destek almadıklarını beyan etmişlerdir.

\section{Kaynaklar}

1. Heart disease and stroke statistics 2012 update: a report from the American Heart Association. Circulation 2012; 121: 46-215.

2. D’Agostino RB Sr, Vasan RS, Pencina MJ, Wolf PA, Cobain M, Massaro JM, et al. General cardiovascular risk profile for use in primary care: the Framingham Heart Study. Circulation 2008; 117 : 743-53. [CrossRef]

3. Onat A, Uysal Ö, Hergenç G. TEKHARF Çalışması orijinal kohortunun Framingham risk fonksiyonuna göre değerlendirilmesi: Halkımızın mutlak koroner riskinin yüksekliğine ilişkin bir ek kanıt. Türk Kardiyol Dern Arş 2001; 29: 208-14.

4. Kovanen PT, Pentikainen MO. Decorin links low-density lipoproteins (LDL) to collagen: a novel mechanism for retention of LDL in the atherosclerotic plaque. Trends Cardiovasc Med 1999; 9: 86-91. [CrossRef]

5. Saikku P, Leinonen M, Mattila K, Ekman MR, Nieminen MS, Mäkelä PH, et al. Serological evidence of an association of a novel Chlamydia, TWAR, with chronic coronary heart disease and acute myocardial infarction. Lancet 1988; 2: 983-6. [CrossRef]

6. Freidman M, Van den Bovenkamp G. The pathogenesis of a coronary trombus. Am J Pathol 1966; 48: 19-31.

7. Endres M, Laufs U, Merz H, Kaps M. Focal expression of intercellular adhesion molecule- 1 in the human carotid bifurcation. Stroke 1997; 28: 77-82. [CrossRef]

8. Tipping PG, Hancock WW. Production of tumor necrosis factor and interleukin-1 by macrophages from human atheromatous plaques. Am J Pathol 1993; 142: 1721-8.

9. Patel L, Buckels AC, Kinghorn IJ, Murdock PR, Holbrook JD, Plumpton C, et al. Resistin is expressedin human macrophages and directly regulated by PPAR gamma activators. Biochem Biophys Res Commun 2003; 300: 472-6. [CrossRef]

10. Kawanami D, Maemura K, Takeda N, Harada T, Nojiri T, Imai Y, et al. Direct reciprocal effects of resistin and adiponectin on vascular endothelial cells: a new insight into adipocytokine-endothelial cell interactions. Biochem Biophys Res Commun 2004; 314: 415-9. [CrossRef]

11. Schäffler A, Büchler C, Müller-Ladner U, Herfarth H, Ehling A, Paul G, et al. Identification of variables influencing resistin serum levels in patients with type 1 and type 2 diabetes mellitus 2004; Horm Metb Res 36: 702-7.

12. Reilly MP, Lehrke M, Wolfe ML, Rohatgi A, Lazar MA, Rader DJ. Resistin is an inflammatory marker of atherosclerosis in humans 2005; Circulation. 2005; 111: 932-9. [CrossRef]

13. American Diabetes Association. Diagnosis and Classification of Diabetes Mellitus. Diabetes Care 2011; 34: 62-9. [CrossRef]

14. Ross R. The Pathogenesis of atherosclerosis. Heart Disease: A Textbook of Cardiovascular Medicine, 5th edition, WB Saunders Company, 1997.

15. Reckless J, Rubin EM, Verstuyft JB, Metcalfe JC, Grainger DJ. Monocyte chemoatractant protein-1 but not tumor necrosis factor- 
alfa is correlated with monocyte infiltration in mouse lipid lesions. Circulation 1999; 99: 2310-6. [CrossRef]

16. Weikert C, Westphal S, Berger K, Dierkes J, Möhlig M, Spranger $\mathrm{J}$, et al. Plasma resistin levels and risk of myocardial infarction and ischemic stroke. J Clin Endocrinol Metab 2008; 93: 2647-53. [CrossRef]

17. Hoefle G, Saely CH, Risch L, Koch L, Schmid F, Rein P, et al. Relationship between the adipose-tissue hormone resistin and coronary artery disease. Clin Chim Acta 2007; 386: 1-6. [CrossRef]

18. Pischon T, Bamberger CM, Kratzsch J, Zyriax BC, Algenstaedt P, Boeing $\mathrm{H}$, et al. Association of plasma resistin levels with coronary heart disease in women. Obes Res 2005; 13: 1764-71. [CrossRef]

19. Burnett MS, Devaney JM, Adenika RJ, Lindsay R, Howard BV. Cross-sectional associations of resistin, coronary heart disease, and insulin resistance. J Clin Endocrinol Metab 2006; 91: 64-8. [CrossRef]

20. Steppan CM, Bailey ST, Bhat S, Brown EJ, Banerjee RR, Wright $\mathrm{CM}$, et al. The hormone resistin links obesity to diabetes. Nature 2001; 409: 307-12. [CrossRef]
21. Matsubara M, Maruoka S, Katayose S. Inverse relationship between plasma adiponectin and leptin concentrations in normalweight and obese women. Eur J Endocrinol 2002; 147: 173-80. [CrossRef]

22. Shari S Bassuk, Nader Rifai, Paul M Ridker. Highsensitivity C-reactive protein: Clinical importance. Curr Probl Cardiol 2004; 29: 439-93. [CrossRef]

23. Berger A. Resistin: a new hormone that links obesity with type 2 diabetes, BMJ 2001; 322: 193.

24. Ling C, Kindblom J, Wennbo H, Billig H. Increased resistin expresssion in the adipose tissue of male prolactin transgenic mice and in male mice with elevated androgen levels. FEBS lettters 2001; 505: 147-50. [CrossRef]

25. Prugger C, Luc G, Haas B, Morange PE, Ferrieres J, Amouyel P, et al. Multiple biomarkers for the prediction of ischemic stroke: the PRIME study. Arterioscler Thromb Vasc Biol. 2013; 33: 659-66. [CrossRef]

26. Beers MH, Berkow R. The Merck Manual of Diagnosis and Therapy, 17th Edition, Merck \& Co., Inc, 2008. 